\title{
The Effect of Merger on Performance: Evidence from the UAE
}

\author{
Manuel Fernandez ${ }^{1}$ and Rajesh Kumar ${ }^{2}$
}

\begin{abstract}
This study analyses the largest banking merger in the Middle East: Emirates Bank International merged with National Bank of Dubai to form the Emirates NBD. The study examines the effect of the merger on the wealth of shareholders and on the operating performance of Emirates NBD. The result shows that during the year surrounding the post-merger period, stock prices increased thereby enhancing the shareholders wealth and the operating performances also improved after the merger.
\end{abstract}

Keywords: merger, stock price, operating profit.

DOI: http://dx.doi.org/10.4314/ejbe.v4i1.3

Manuel Fernandez ${ }^{1}$, PhD, Associate Professor, Skyline University College, P.O. Box 1797 University City of Sharjah, Sharjah, UAE, mfernandez@skylineuniversity.ac.ae, qln_manuel@yahoo.com Rajesh Kumar ${ }^{2}$, Associate Professor, IMT-Dubai, PO Box 345006, Academic City Dubai, UAE, rajesh@imtdubai.ac.ae, rajesh155_bk@yahoo.com 
UAE: Mergers and Acquisitions

\section{Introduction}

Consolidation of business entities is a world-wide phenomenon. One of the tools for consolidation is mergers and acquisitions. For any firm with the objective of stockholder wealth maximization, the appropriate test of a successful merger is the effect of merger on its stock prices. In an efficient capital market, investor's expectations of the merger's future benefit should be fully reflected in stock prices by the merger date. Whereas, if the capital markets are semi strong efficient, then the value of future benefits should be fully reflected by the first public announcement of the merger and should certainly be fully reflected by somewhat later merger date. The increase in the equity value of the acquiring firm in the wake of a successful merger is a compelling evidence for the synergy theory of mergers. M\&A results in the achievement of cost based and revenue based synergies. The cost based synergy is achieved by reducing the costs incurred by combining similar assets in the merged businesses. Revenue based synergy can be exploited if merging businesses develop new competencies that allow them to command a price premium through higher innovation capabilities or to boost sales volume through increased market coverage both geographically and by product line extension.

\section{Objective of the study}

In the theoretical context, a merger has to lead to synergistic benefits of cost and revenue. This study was carried out to investigate whether the EBI-NBD merger has yielded fruitful results with respect to economic value addition and enhancement of shareholder wealth. The analysis was done with respect to both the share price and operating performance. 
UAE: Mergers and Acquisitions

\section{1 $\mathrm{M}$ and $\mathrm{A}$ in the MENA Region}

Announced deal values in the (Middle East and North Africa) MENA region rose from $\$ 44.8$ billion (Dh164.5 billion) in 2012 to $\$ 50.7$ billion (Dh186.2 billion) in 2013. 442 deals were announced in 2013 as compared to 398 deals in 2012, an increase of 11 per cent (Ernst \& Young's, 2013). The UAE topped the MENA region in terms of total value of disclosed domestic merger and acquisition deals, comprising approximately 54 per cent (worth $\$ 2.2$ billion), followed by Qatar at 21 per cent (worth $\$ 880.4$ million). Of the top 10 announced deals by value in MENA in 2013, five of the deals were acquired by UAE companies and two of the deals were acquired by Qatari companies. The largest M\&A deal of 2013 was the merger of Dubai Aluminum with Emirates Aluminum for $\$ 7.5$ billion (Dh27.5 billion), followed by the acquisition of Itissalat Al Maghrib SA (Maroc Telecom) in Morocco by Emirates Telecommunications Corporation(etisalat) in the UAE for \$6.1 billion (Dh22.4 billion).

Figure 1: M\& A in the UAE: 1999-2013

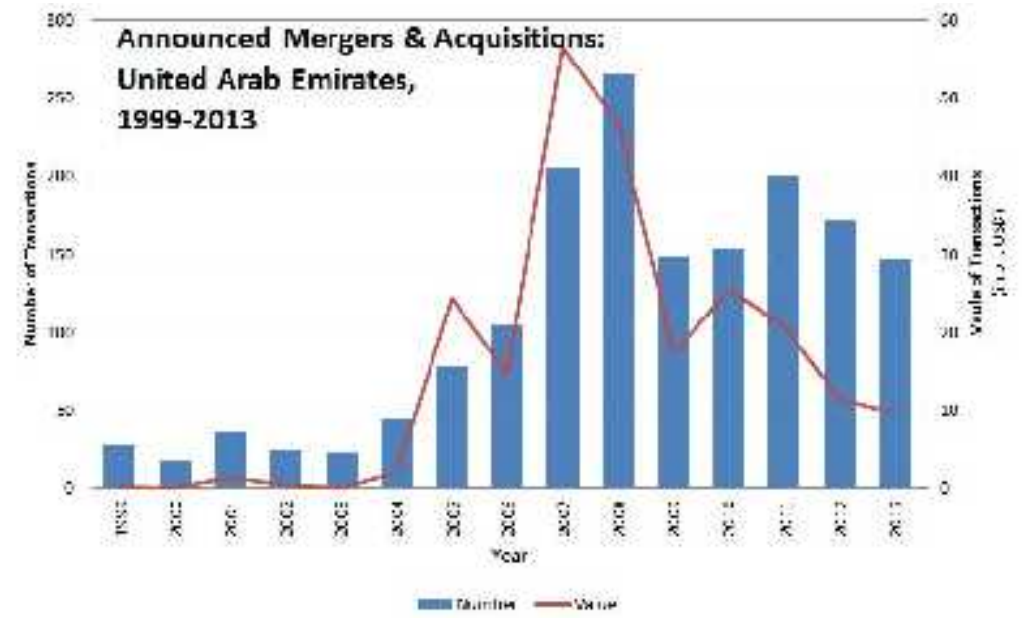

Source: Thomson Financial, Institute of Mergers, Acquisitions and Alliances (IMAA) analysis 
UAE: Mergers and Acquisitions

\section{GCC Banking Sector}

The GCC (Gulf Cooperation Council) banking sector recorded an improved performance in 2012 and 2013. Most banks have booked higher profits in 2013, driven by increased loan asset growth, wider interest margins, greater fee and commission income and lower loan loss provisioning charges.

Table 1: GCC's Top 10 Banks in 2012

\begin{tabular}{|l|l|l|r|r|}
\hline Rank & \multicolumn{1}{|c|}{ Bank Country } & \multicolumn{1}{|c|}{$\begin{array}{c}\text { Assets } \\
\text { (US\$000) }\end{array}$} & $\begin{array}{c}\text { Net Profit } \\
\text { (US\$000) }\end{array}$ \\
\hline 1 & Qatar National Bank & Qatar & $100,784,020$ & $2,314,022$ \\
\hline 2 & National Commercial Bank & KSA & $92,085,369$ & $1,763,554$ \\
\hline 3 & Emirates NBD & UAE & $83,935,843$ & 695,350 \\
\hline 4 & $\begin{array}{l}\text { National Bank of Abu } \\
\text { Dhabi }\end{array}$ & UAE & $81,840,231$ & $1,179,479$ \\
\hline 5 & $\begin{array}{l}\text { Al Rajhi Banking } \\
\text { Corporation }\end{array}$ & KSA & $71,302,017$ & $2,102,588$ \\
\hline 6 & National Bank of Kuwait & Kuwait & $58,418,947$ & $1,097,624$ \\
\hline 7 & Samba & KSA & $53,126,437$ & $1,155,226$ \\
\hline 8 & Kuwait Finance House & Kuwait & $52,296,998$ & 438,634 \\
\hline 9 & Riyad Bank & KSA & $50,714,890$ & 924,280 \\
\hline 10 & $\begin{array}{l}\text { Abu Dhabi Commercial } \\
\text { Bank }\end{array}$ & UAE & $49,222,903$ & 765,133 \\
\hline
\end{tabular}

Source: http://gulfbusiness.com

\section{Emirates NBD}

"Emirates NBD", the leading banking group in the Middle East, was formed on $16^{\text {th }}$ of October 2007 when the shares of Emirates NBD were officially listed on the Dubai Financial Market (DFM). Emirates NBD is a market leader across core business lines and the leading retail banking franchise, with 219 branches and over 920 ATMs and Cash Deposit Machines (CDMs) spread across the country and overseas. It is a major player in the corporate banking arena. With fast growing Islamic banking affiliated entities, strong investment and private 
UAE: Mergers and Acquisitions

banking services and a leadership in the field of asset management products and brokerage services. As at 31 December 2013, total assets were AED 342.1 billion. The Group has operations in the UAE, Egypt, the Kingdom of Saudi Arabia, Qatar, Singapore, the United Kingdom, and representative offices in India, China and Indonesia. Currently, more than 9,000 people, representing 70 nationalities, are employed by Emirates NBD, making it one of the largest and most culturally diversified employers in the UAE.

\subsection{Highlights of the Merger}

The merger was announced on March 6, 2007. The Emirates NBD, merger between Emirates Bank International (EBI) and the National Bank of Dubai (NBD), became a regional consolidation blueprint for the banking and finance sector as it combined the second and fourth largest banks in the United Arab Emirates (UAE) to form a banking champion capable of delivering enhanced value across corporate, retail, private, Islamic and investment banking throughout the region. This merger was in tune with the high levels of growth achieved by the banking industry over the past few years on the back of the booming UAE and regional economies. During the period of pre-merger three years, the UAE GDP grew at an average rate of 20 per cent. In 2007 the total assets of UAE banks grew by 45 per cent to US $\$ 337$ billion. The value of deposits grew by 35 per cent to US $\$ 204$ billion.

The merger resulted in the union of two powerful legacies which was aimed to become a leading regional financial institution with an increasing international presence. The merger was aimed to leverage financial strength, scale and market positioning to capture domestic and regional opportunities. The merger facilitated the partnership for wholesale, retail, investment, treasury and 
Islamic banking clients. The total income of the two banks reached AED 7.1 billion, an increase of 50 per cent year on year. The group became a major player in the corporate banking arena with a joint market share of almost a fifth of corporate loans. This strategic merger was meant to create a bank with scale, financial strength and service quality standards to compete effectively in a dynamic market.

The merger created the largest UAE bank by assets and market capitalization, significantly enhanced competitiveness by strategically positioning to capture high growth potential of domestic and regional markets. It became corporate and retail banking powerhouse with highly diversified business mix and largest distribution network in the UAE. 
UAE: Mergers and Acquisitions

\subsection{Superior Value Creation Potential}

Expected significant cost and revenue synergies driving value creation:

Table 2: Significant Events

\begin{tabular}{|l|l|}
\hline \multicolumn{1}{|c|}{ Date } & \multicolumn{1}{|c|}{ Events } \\
\hline 06 March 2007 & $\begin{array}{l}\text { The merger between Emirates Bank and National Bank } \\
\text { of Dubai was announced }\end{array}$ \\
\hline 14 March 2007 & A Merger steering committee was appointed \\
\hline 09 April 2007 & $\begin{array}{l}\text { Goldman Sachs International appointed as lead financial } \\
\text { advisors on the merger }\end{array}$ \\
\hline 12 July 2007 & $\begin{array}{l}\text { Emirates Bank and National Bank of Dubai announced } \\
\text { terms of their merger }\end{array}$ \\
\hline 05 September 2007 & $\begin{array}{l}\text { Emirates Bank Shareholders approved the merger terms } \\
\text { at Extraordinary General meeting }\end{array}$ \\
\hline 06 September 2007 & $\begin{array}{l}\text { National Bank of Dubai shareholders approved the } \\
\text { merger's terms at an Extraordinary General Meeting }\end{array}$ \\
\hline 18 September 2007 & $\begin{array}{l}\text { Emirates NBD closed its initial offer to shareholders of } \\
\text { National Bank of Dubai and Emirates Bank }\end{array}$ \\
\hline 08 October 2007 & $\begin{array}{l}\text { Emirates bank and National Bank of Dubai's shares were } \\
\text { suspended from trading on the Dubai Financial Market }\end{array}$ \\
\hline 16 October 2007 & $\begin{array}{l}\text { Trading began on shares in Emirates NBD PJSC, the } \\
\text { newly merged banking group listed on the Dubai } \\
\text { Financial Market. }\end{array}$ \\
\hline 18 October 2007 & $\begin{array}{l}\text { Emirates NBD announced the integration of its ATM } \\
\text { Network making it the largest in the UAE. }\end{array}$ \\
\hline 04 November 2007 & $\begin{array}{l}\text { The National Bank of Dubai's building became the new } \\
\text { headquarters for Emirates NBD. }\end{array}$ \\
\hline
\end{tabular}

\subsection{Financial Highlights}

The significance of the merger of Emirates Bank International (EBI) and National Bank of Dubai (NBD) was reflected in the strong pro forma results of Emirates NBD. The total income reached AED7.1 billion on a pro forma basis. The primary drivers for the increase in total income were robust growth in customer assets supported by a rise in customer deposits across both the retail and wholesale businesses. The group continued to maintain a healthy mix of 
UAE: Mergers and Acquisitions

funded and non-funded income. The growth in income was supported by a steady increase in fee based product revenue.

The operating cost for Emirates NBD was AED 2.7 billion on a pro forma basis, an increase of 51 per cent over 2006. The increase in costs was driven by continued investments in expanding distribution and product capabilities, building robust infrastructure and developing strong governance capabilities.

The net profits of the Group were AED 4 billion (excluding amortization of intangibles) for 2007 on a pro forma basis, an increase of 35 per cent over 2006. Emirates NBD reported a 25.12 per cent return on average shareholder equity, a 1.6 per cent increase over 2006. Total assets recorded at the end of 2007 were AED 253.8 billion, an increase of 53 per cent for EBI and NBD's combined assets in 2006.This positioned Emirates NBD with a 20.5 per cent market share of banking assets in the UAE and as the largest bank in the Middle East.

\subsection{Business Highlights}

Emirates NBD's wholesale banking's net income (excluding IPO business) grew by 38 per cent and its assets by 42 per cent in the year 2007.The Structured Finance and Syndication Division (SFS) remained at the forefront of the UAE's loan syndication market in 2007.The division gained a significant share in the local debt syndication market in value and number of deals acting as mandated lead arrangers and book runners in a number of high profile transactions. The division also led managed multiple benchmark transactions for the UAE's largest and highest profile issuers in the year 2007. The Financial Institutions Division (FDI) became an important contributor to the wholesale banking sector in the year 2007. 
UAE: Mergers and Acquisitions

\subsection{Consumer Banking and Wealth Management}

As a result of the merger, the Group's distribution network became the largest in the UAE. Emirates NBD ended the year with a total of 88 retail branches following the opening of 13 new outlets. The number of ATMs increased to 440. The expansion of the Al Shaheen and Suhail branch network to 27 in 2007 positioned the Bank with the largest network of affluent banking centers in the country. Growth in customer deposits and loans was strong in 2007 outperforming the market growth. With the advent of cross selling across the integrated group, improved delivery across all channels and a partnership with the UK's John Charcoal Brokers facilitated NBD to become the UAE's leading non Islamic home loans provider in 2007.

\section{Private Banking}

As part of its expansion strategy, Emirates NBD acquired two new locations in 2007. The Private Banking division worked with its London Office in the introduction of the Hammersmith project to its client base. The Investment Management Group added a mix of mutual funds to its platform in 2007 covering emerging markets, multi manager, global real estate and commodities.

\section{Investment Banking}

NBD Investment Bank provides integrated investment banking, financial markets and private equity solutions and serves the needs of corporations, governments, institutional and high net worth clients across the GCC and wider MENA region. 
UAE: Mergers and Acquisitions

\section{Group Treasury and Markets}

In 2007, the group treasury activities included USD 1.5 billion 5 year syndicated deposit facility; USD 1 billion Sukuk -Trust Certificate Issuance program arranged for Emirates Islamic bank. The Group's new credit structuring and trading areas became fully operational in 2007.The Foreign Exchange and Interest rate trading volumes increased positioning the newly merged group as a leading market maker in GCC currencies. As a result of the merger, the Group's direct international footprint extended to a number of countries outside of UAE namely, Egypt, the Kingdom of Saudi Arabia, Qatar, Singapore, the United Kingdom, and representative offices in India, China and Indonesia.

\section{Information Technology and Operations}

A number of major system initiatives were implemented in the year 2007 including core banking system replacement, the adaptation of an ERP system for EHR and Enterprise Financial Management and the implementation of a state of the art treasury system which enables integrated processing of the front, middle and back offices. A new consumer finance system that processes the complete life cycle of loans was implemented in the year 2007.

The integration of the combined banks Group, ATMs and Smart Deposit Machines (SDMs) were completed by 2008 which rose to more than 650 across UAE making it the biggest network in the country. Mobile and online banking has also been fully integrated with enhanced functionalities and 13 payment partners available to all of the bank's customers. 
UAE: Mergers and Acquisitions

\section{The Key Terms of the Merger}

The creation of Emirates NBD was by the merger of common ownership of EBI and NBD. The salient features of the consideration were 1) Exchange ratio of 0.95 Emirates NBD shares for every NBD share. 2) Exchange ratio of 1 Emirates NBD for every EBI share.

As on July 01 2007, the implied share price for NBD was AED 8.84. The implied share price for EBI was AED 9.30.The implied total consideration was AED 13.75 billion. ${ }^{1}$ The offer price represented 14 per cent premium to the prices on the day prior to announcement.

\section{Synergies Expected from the Merger}

\section{Revenue Synergies}

In the corporate banking, the cross selling of new product capabilities is expected to result in revenue synergy through increase in fee income. In the retail banking sector, the focus will be on incremental revenue generated through market share/pricing advantages and the leveraging of the largest distribution network in the UAE. In the Investment banking sector, expansion of client base and cross selling of new product capabilities is expected to lead to revenue synergies. Revenue synergies also result from improved cost of funding due to a stronger capital base and improved sales due to integrated broader offering.

\footnotetext{
${ }^{1}$ Share price of EBI of AED 10.48 on 5 March 2007, implying a share price for NBD of AED 9.96 based on $0.95 \mathrm{x}$ exchange ratio. Market price of NBD on 5March 2007 of AED 8.75implying $14 \%$ premium. All share prices adjusted for bonus share issues.
} 
UAE: Mergers and Acquisitions

\section{Cost Synergies}

Cost synergies are expected to result from retail banking due to: Branch and ATM network consolidation; Integration of card acquiring business; and Pricing advantages on advertising /marketing spend. The cost synergy is also expected from optimized head office and group functions. Cost synergies would also result from reallocation of IT personnel from NBD to EBI IT dedicated center. Cost synergies are also expected from brokerage due to improved efficiency from integrated operations and IT platform. Cost synergies are also expected from leveraging Emirates Islamic Bank as a platform for unified Islamic offerings.

\section{Literature Review}

Two main research approaches explain Mergers and Acquisition profitability. The event studies examine the abnormal returns to shareholders in the period surrounding the announcement of a merger or acquisition. The accounting studies examine the reported financial results of acquirers before and after the acquisitions to see how the financial performance changes. It is a wellestablished fact that target shareholders gain when a merger, acquisition or tender offer is announced.

\subsection{Stock Market Studies}

Most of the broad based risk adjusted studies on mergers like those of Mandelker (1974) and Langeteig (1978) have shown that the stockholders of acquiring firms either gain a small, statistically insignificant amount or as in the study by Dodd(1980) lose a small significant amount from the announcement of a merger bid. The study by Asquith et al (1983) examines the 
effect of mergers on the wealth of bidding firms shareholders. Bidding firms gain significantly during the twenty-one days leading to the announcement of each of their first four merger bids. The results fail to support the capitalization hypothesis that bidder's gains are captured at the beginning of merger programs. The study by Langetieg (1978) employs four alternative two-factor market industry models in combination with a matched non-merging control group to measure stockholder gains from mergers. Moeller et al (2004) examined the announcement returns using a sample of 12,023 acquisitions by public firms during the period 1980-2001. The results of this study show that the equally weighted abnormal announcement returns is 1.1 per cent but acquiring firm shareholders lose $\$ 25.2$ million on average upon announcement. Moeller et al (2004) find that acquisition announcements in the 1990s are profitable in the aggregate for acquiring firm shareholders until 1997, but the losses of acquiring firm shareholders from 1998 through 2001 wiped out all gains made earlier thereby making acquisitions announcements in the latest merger wave costly for acquiring firm shareholders.

\subsection{Operating Performance Studies}

Palepu (1985) finds that there is no significant cross-sectional difference between the profitability of firms with predominantly related and unrelated diversification; and profitability of firms with high and low total diversification. Moreover, the study finds that the superior profitability growth of related diversifiers is significantly greater than that of unrelated diversifiers. Herman and Lowenstein (1988) examined the post-merger performance of a sample of hostile acquisitions between 1975 and 1983. The study by Paul M. Healy and Palepu (1992) examines the post-merger cash flow performance of acquiring and target firms and explores the sources of merger induced changes 
UAE: Mergers and Acquisitions

in cash flow performance based on 50 largest US mergers between 1979 and mid-1984. The study finds that merged firms show significant improvements in asset productivity relative to their industries, leading to higher operating cash flow returns. These improvements were particularly strong for transactions involving firms in overlapping business. The study further suggests that postmerger cash flow improvements do not come at the expense of long term performance since sample firms maintain their capital expenditure and R\&D rates relative to their industries after the merger. The study also found strong positive relation between post-merger increases in operating cash flows and abnormal stock returns at merger announcements indicating that expectations of economic improvements explain a significant portion of the equity revaluation of the merging firms. Cornett and Tehranian (1992) examine the post-acquisition performance of large bank merger between 1982 and 1987.The results of their study indicate better performance for merged banks due to the improvements in ability to attract loans and deposits, in employee productivity and in profitable asset growth. Further, the study finds a significant correlation between announcements period abnormal return and the various performance measures indicating that the market participants are able to identify in advance the improved performance associated with bank acquisitions. Switzer (1996) examined the change in operating performance of merged firms using a sample of 324 combinations, which occurred between 1967 and 1987. The results indicated that the performance of the merged following their combinations and also the results are not sensitive to factors such as offer size, industry relatedness between the bidder's and target's businesses or bidder's leverage. The study also found positive association between the abnormal revaluation of the firms involved around the merger and changes in operating performance observed. The study by Healy et al (1997) 
UAE: Mergers and Acquisitions

found that strategic takeovers which are generally friendly transactions involving stock and firms in overlapping business are more profitable than financial deals which are usually hostile transactions involving cash and firms in unrelated business. The results of this study also showed that the acquiring companies did not generate any additional cash flows beyond those needed to recover the premium paid. Ghosh (2001) compares the post and pre acquisition performance of merging firms relative to matched firms to determine whether operating cash flow performance improves following acquisition. The result found no evidence of improvement of operating performance following acquisitions.

\section{Methodology}

\subsection{Stock Price Analysis}

The studies of abnormal returns provide a basis for examining the issue of whether or not value is enhanced by mergers. The study analyses the share price performance using market adjusted method.

The market's reaction to a merger bid is measured using daily stock return data to compute excess stockholder returns. These excess returns are a measure of the stockholder's return from the new information which becomes available to market. The daily excess return for the security is estimated by

$\mathrm{XRt}=\mathrm{Rt}-\mathrm{E}(\mathrm{Rt})$

Where $t=$ day relative to an event.

XRt $=$ Excess return on the security for day $\mathrm{t}$.

$\mathrm{Rt}=$ Actual Return on the security for day $\mathrm{t}$.

$\mathrm{E}(\mathrm{Rt})=$ Expected rate of return on the security for day $\mathrm{t}$.

The excess return for a time window period is cumulated to get the Cumulative Abnormal Return (CAR).

EJBE Vol. 4 No. 1/2014 
The choice of the benchmark is probably the most important factor in making accurate measurement of a merger's impact.

The expected rate of return on the security is found out using the Market Return Adjusted Method.

The predicted return for a firm for a day in the event period is just the return on the market index. The market index used in the study is DFM index.

$\mathrm{Rt}=\mathrm{Rmt}$.

Where Rt is the expected return. Rmt is the market index return. The merger date used was the announcement date. The day of announcement of the merger is titled $\mathrm{t}=0$, the days before as $-1,-2$ etc. and the post-merger days as $+1,+2$ etc.

\subsection{Operating Performance Analysis} Model for Analysis of Operating Performance:

Total Operating cash flow return on assets is defined as profit before depreciation, interest and taxes divided by the book value of assets.

Cash flow return on Assets $(\mathrm{CFA})=$ Total Operating cash flow $\div$ Book Value of assets 
UAE: Mergers and Acquisitions

\subsection{Share Price Analysis and Interpretation}

Table3: NBD Share Price Daily Returns during the announcement period

\begin{tabular}{|r|r|r|}
\hline Day t & $\begin{array}{c}\text { Return in } \\
\text { percentage }\end{array}$ & $\begin{array}{c}\text { Cumulative Return in } \\
\text { percentage }\end{array}$ \\
\hline-5 & 0 & 0 \\
\hline-4 & 0.975 & 0.975 \\
\hline-3 & 1.44 & 2.415 \\
\hline-2 & -1.9 & 0.515 \\
\hline-1 & 1.94 & 2.455 \\
\hline 0 & 0.47 & 2.925 \\
\hline 1 & 4.73 & 7.655 \\
\hline 2 & 0.45 & 8.105 \\
\hline 3 & -5.8 & 2.305 \\
\hline 4 & -0.47 & 1.835 \\
\hline 5 & 1.92 & 3.755 \\
\hline
\end{tabular}

Figure 2: Share Price Returns for NBD during the merger announcement period $(-40$ to +40 day)

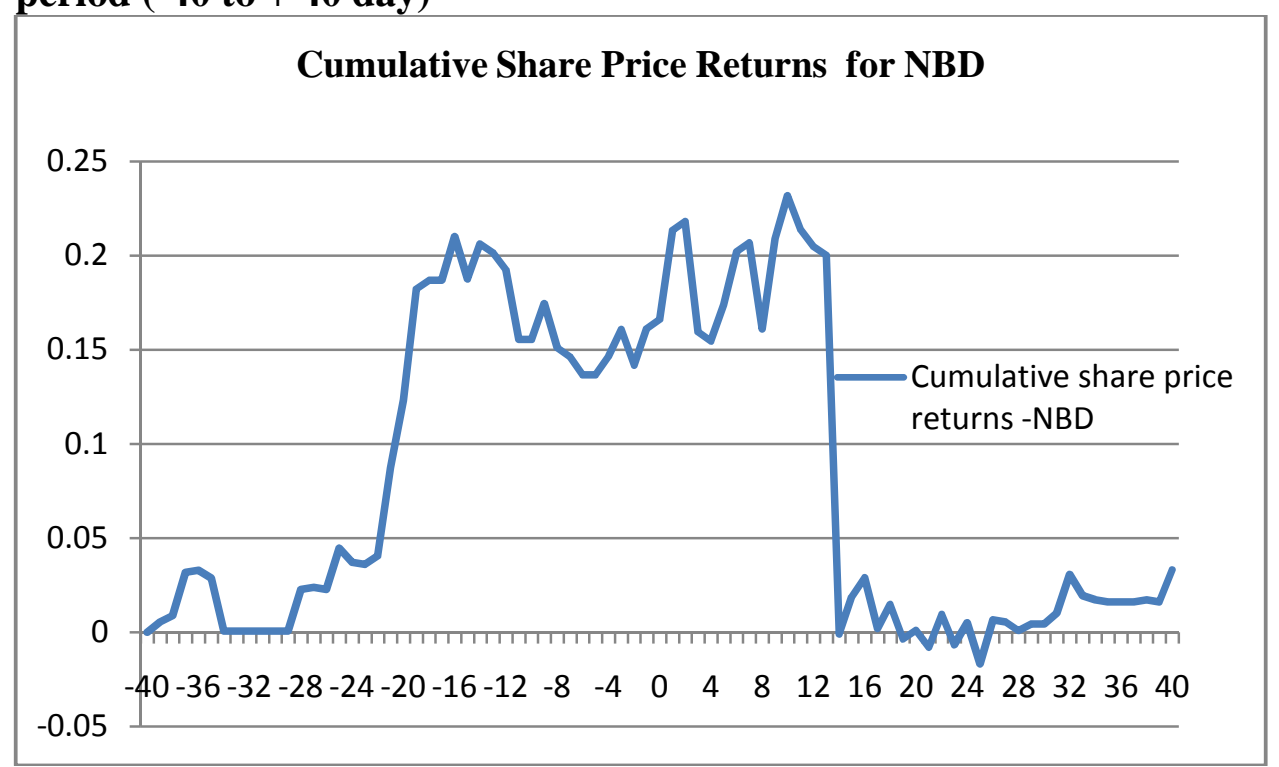

Figure 2 shows that there have been increased returns for NBD during the immediate merger announcement period. There has been a drastic upward 
UAE: Mergers and Acquisitions

movement in the cumulative share price returns after day -22 of the merger announcement period followed by volatility in the share price returns and finally a drastic downfall in the price movement after +13 day of announcement.

Table 4: Cumulative Returns for NBD during different time windows

\begin{tabular}{|c|c|}
\hline $\begin{array}{c}\text { Time Window surrounding } \\
\text { announcement }\end{array}$ & $\begin{array}{c}\text { Cumulative Return } \\
\text { in percentage }\end{array}$ \\
\hline-40 to +40 days & 1.70 \\
\hline-20 to +20 days & -8.6 \\
\hline-10 to +10 days & 7.62 \\
\hline-5 to +5 days & 3.755 \\
\hline-3 to +3 days & 1.29 \\
\hline-2 to +2 days & 5.70 \\
\hline-1 to +1 days & 7.15 \\
\hline
\end{tabular}

The announcement day return for NBD was 0.47 per cent. The share price return for NBD was 4.73 per cent for the day immediately after the announcement. The previous day before the announcement documented a return of 1.94 percent for the NBD bank. An analysis of different time window periods reveals that the maximum cumulative return of 7.62 per cent was observed during the 21day period $(-10$ to +10$)$.During the three day window period $(-1$ to +1$)$ the cumulative return was 7.15 per cent. During the time window of 11 days $(-5$ to +5$)$ surrounding the merger announcement, the cumulative share price return was 3.755 per cent. 
UAE: Mergers and Acquisitions

Table 5: EBI Share Price Daily Returns during the announcement period

\begin{tabular}{|c|r|r|}
\hline Day t & $\begin{array}{c}\text { Return in } \\
\text { percentage }\end{array}$ & $\begin{array}{c}\text { Cumulative Return } \\
\text { in percentage }\end{array}$ \\
\hline-5 & -2.86 & -2.86 \\
\hline-4 & -2.95 & -5.81 \\
\hline-3 & -0.38 & -6.19 \\
\hline-2 & 4.19 & -2 \\
\hline-1 & -4.02 & -6.02 \\
\hline 0 & -3.05 & -9.07 \\
\hline 1 & 7.48 & -1.59 \\
\hline 2 & -3.60 & -5.19 \\
\hline 3 & -1.14 & -6.33 \\
\hline 4 & -1.92 & -8.25 \\
\hline 5 & 1.96 & -6.29 \\
\hline
\end{tabular}

The analysis documents a return of 7.48 per cent for Emirates Bank International in the day immediately after the announcement of merger. The share price returns were negative during both -1 and the day of announcement. During the time window period of -5 to +5 days, only the +1 and +5 day surrounding the announcement period documented positive share price returns. 
Figure 3: Share Price Returns for EBI during the merger announcement period $(-40$ to +40 day $)$

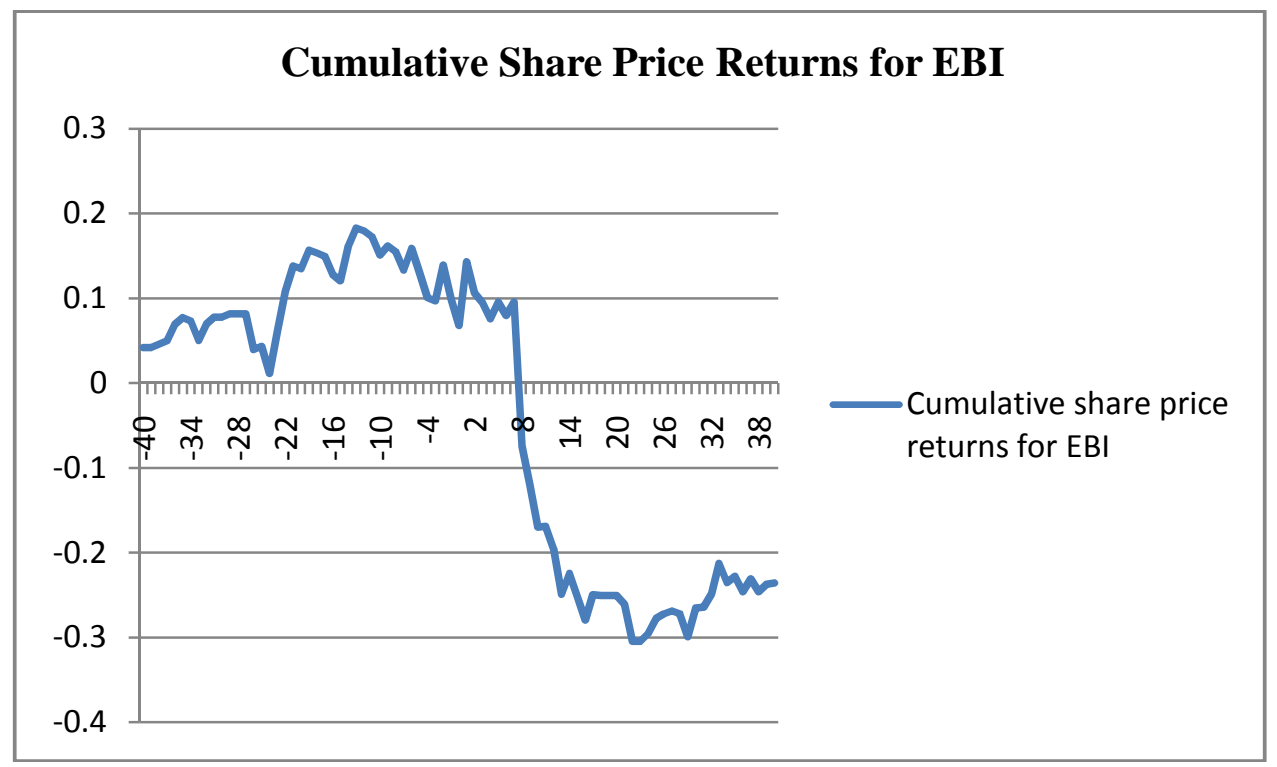

The figure above reveals that the share price returns were positive in the premerger period with a declining trend in the post-merger period. There have been positive returns in the period immediately surrounding the merger announcement.

Table 6: Cumulative Returns for EBI during different time windows

\begin{tabular}{|c|c|}
\hline $\begin{array}{c}\text { Time Window surrounding } \\
\text { announcement }\end{array}$ & $\begin{array}{c}\text { Cumulative Return } \\
\text { in percentage }\end{array}$ \\
\hline-40 to +40 days & -23.57 \\
\hline-20 to +20 days & -38.87 \\
\hline-10 to +10 days & -34.18 \\
\hline-5 to +5 days & -6.37 \\
\hline-3 to +3 days & -0.58 \\
\hline-2 to +2 days & 0.93 \\
\hline-1 to +1 days & 0.39 \\
\hline
\end{tabular}

EJBE Vol. 4 No. 1/2014 
UAE: Mergers and Acquisitions

From the table, it is observed that only during the shorter time window period of -2 to +2 and 3 day period of -1 to +1 , the share price returns are positive. All other time window period registered negative returns with 41 day and 21 day period having negative returns of approximately 39 per cent and 34 per cent respectively. For the eighty one day period $(-40$ to +40$)$, the cumulative return was negative 23.57 per cent.

It can be stated that the cumulative share price returns were positive for NBD in different time window periods, except the window period -20 to +20 . In comparison, EBI's share price returns were highly negative in larger window periods.

\subsection{Abnormal Return (Excess return) and Cumulative Abnormal Return Analysis ${ }^{2}$}

Table 7: NBD's Excess Returns during the announcement period

\begin{tabular}{|r|c|}
\hline Day t & $\begin{array}{c}\text { Excess Return in } \\
\text { percentage }\end{array}$ \\
\hline 1 & 3.89 \\
\hline 2 & 3.39 \\
\hline 3 & -3.25 \\
\hline 4 & 5.74 \\
\hline 5 & 1.44 \\
\hline 6 & 7.07 \\
\hline 7 & 0.95 \\
\hline 8 & -9.02 \\
\hline 9 & 9.05 \\
\hline 10 & 1.78 \\
\hline
\end{tabular}

\footnotetext{
2 The time window period for the abnormal or excess return takes the lower limit of time period as $t=1$ (day after the announcement period of merger) due to non availability of DFM index values. The data values were available only from the last day of the first week of March 2007.
}

EJBE Vol. 4 No. $1 / 2014$ 
The excess return or abnormal analysis for NBD reveals that on the day after the merger announcement, NBD had an abnormal return of 3.89 per cent. The highest abnormal return was observed on the $9^{\text {th }}$ day after merger announcement $(9.05 \%)$. Negative abnormal returns were observed during the + 3 and +8 day of announcement.

\section{Table 8: Cumulative Abnormal Returns for NBD during different time} windows

\begin{tabular}{|c|r|}
\hline $\begin{array}{c}\text { Time Window surrounding } \\
\text { announcement }\end{array}$ & $\begin{array}{l}\text { Cumulative Abnormal } \\
\text { Return in percentage }\end{array}$ \\
\hline+1 to +40 day & -31.97 \\
\hline+1 to +20 day & -4.97 \\
\hline+1 to +10 day & 21.06 \\
\hline+1 to +5 day & 11.22 \\
\hline+1 to +3 day & 4.02 \\
\hline+1 to +2 day & 7.2 \\
\hline
\end{tabular}

The CAR analysis for NBD documents positive abnormal returns during the shorter time window period surrounding the merger announcement. The CAR during the time window period of +1 to +10 day was 21.06 per cent. The CAR analysis revealed negative abnormal returns during the longer time window period. 
UAE: Mergers and Acquisitions

Figure 4: CAR for NBD during the Post-merger announcement period (+1 to +40 day)

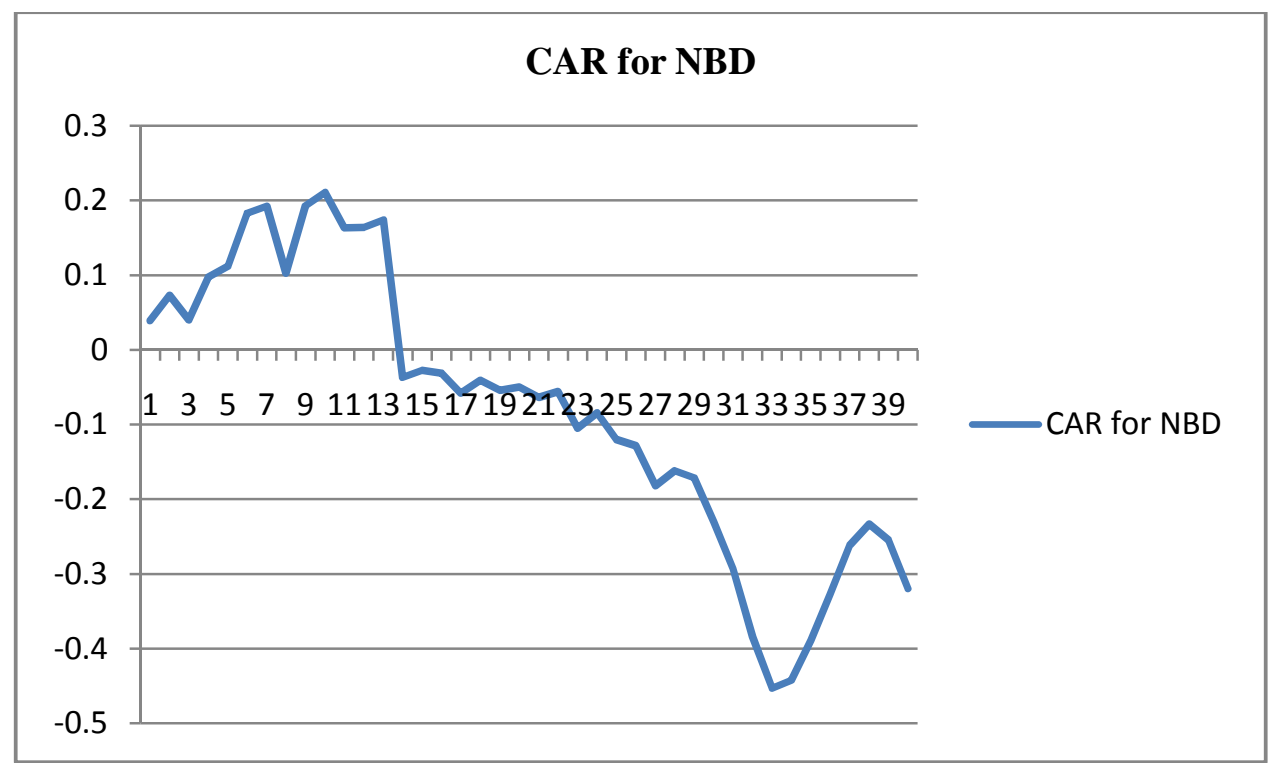

The figure 4 shows that the cumulative abnormal returns for NBD were showing a positive upward movement during the days immediately after the announcement day. The CAR increased up to +6 day and then started fluctuating. Beyond +14 day of announcement, the CAR showed a negative downward movement 
UAE: Mergers and Acquisitions

Table 9: EBI's Excess Returns during the announcement period

\begin{tabular}{|c|c|}
\hline Day t & $\begin{array}{c}\text { Excess Return in } \\
\text { percentage }\end{array}$ \\
\hline 1 & 6.6 \\
\hline 2 & 5.9 \\
\hline 3 & 7.3 \\
\hline 4 & 11.6 \\
\hline 5 & 13.15 \\
\hline 6 & 15.86 \\
\hline 7 & 17.91 \\
\hline 8 & -3.4 \\
\hline 9 & -3.8 \\
\hline 10 & -9.27 \\
\hline
\end{tabular}

The excess return analysis for EBI reveals an excess return of 6.6 per cent compared to the market index DFM during the day immediately after the merger announcement. The analysis also documents an excess return of $5.9 \%$ and $7.3 \%$ during the +2 and +3 day of announcement. Double digit return was observed during the +4 to +7 day of event announcement. Negative excess return was observed in the following days up to the $10^{\text {th }}$ day of merger announcement.

Table 10: Cumulative Abnormal Returns for EBI during different time windows

\begin{tabular}{|c|r|}
\hline $\begin{array}{c}\text { Time Window surrounding } \\
\text { announcement }\end{array}$ & $\begin{array}{c}\text { Cumulative Abnormal } \\
\text { Return in percentage }\end{array}$ \\
\hline+1 to +40 day & -49 \\
\hline+1 to +20 day & -20.34 \\
\hline+1 to +10 day & -9.27 \\
\hline+1 to +5 day & 13.15 \\
\hline+1 to +3 day & 7.36 \\
\hline+1 to +2 day & 5.9 \\
\hline
\end{tabular}

EJBE Vol. 4 No. 1/2014 
The CAR analysis suggests that Emirates Bank International has positive cumulative abnormal returns during the shorter time window period compared to the negative returns in the longer period of analysis. The study documents a CAR of 5.9 per cent during a-two-day period after the merger announcement. During the 6 day period of +1 to +5 , the study observes a positive CAR of 13.15 per cent.

Figure 5: CAR for EBI during the Post-merger announcement period (+1 to +40 day)

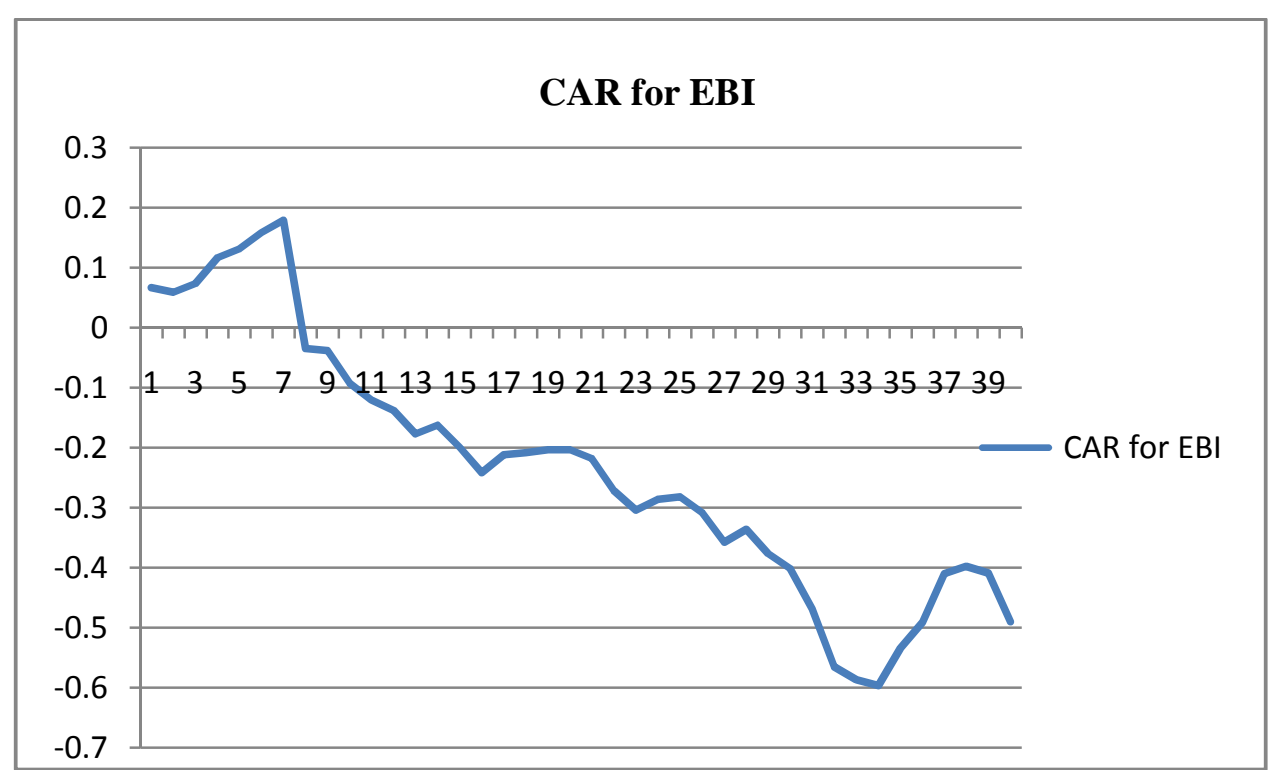

Figure 5 reveals that the cumulative abnormal returns during the immediate days following the merger announcement were positive for EBI. It can be noted that the CAR was showing an increasing upward movement till day +6 and then the movement became downward. 
UAE: Mergers and Acquisitions

Table11: Stock Returns and Cumulative Abnormal Returns surrounding Post-merger Announcement

\begin{tabular}{|c|r|r|}
\hline $\begin{array}{l}\text { Months after } \\
\text { Merger }\end{array}$ & \multicolumn{1}{l|}{ Returns } & \multicolumn{1}{l|}{ CAR } \\
\hline 1 & $2.76 \%$ & $5.60 \%$ \\
\hline 2 & $-1.08 \%$ & $4.53 \%$ \\
\hline 3 & $0.54 \%$ & $5.07 \%$ \\
\hline 4 & $0.00 \%$ & $5.07 \%$ \\
\hline 5 & $70.27 \%$ & $75.34 \%$ \\
\hline 6 & $-17.46 \%$ & $57.88 \%$ \\
\hline 7 & $11.54 \%$ & $69.42 \%$ \\
\hline 8 & $0.69 \%$ & $70.11 \%$ \\
\hline 9 & $0.00 \%$ & $70.11 \%$ \\
\hline 10 & $-7.88 \%$ & $62.23 \%$ \\
\hline 11 & $-9.29 \%$ & $52.94 \%$ \\
\hline
\end{tabular}

Figure 6: Graphical representation of CAR during the first 15 months Post-merger announcement

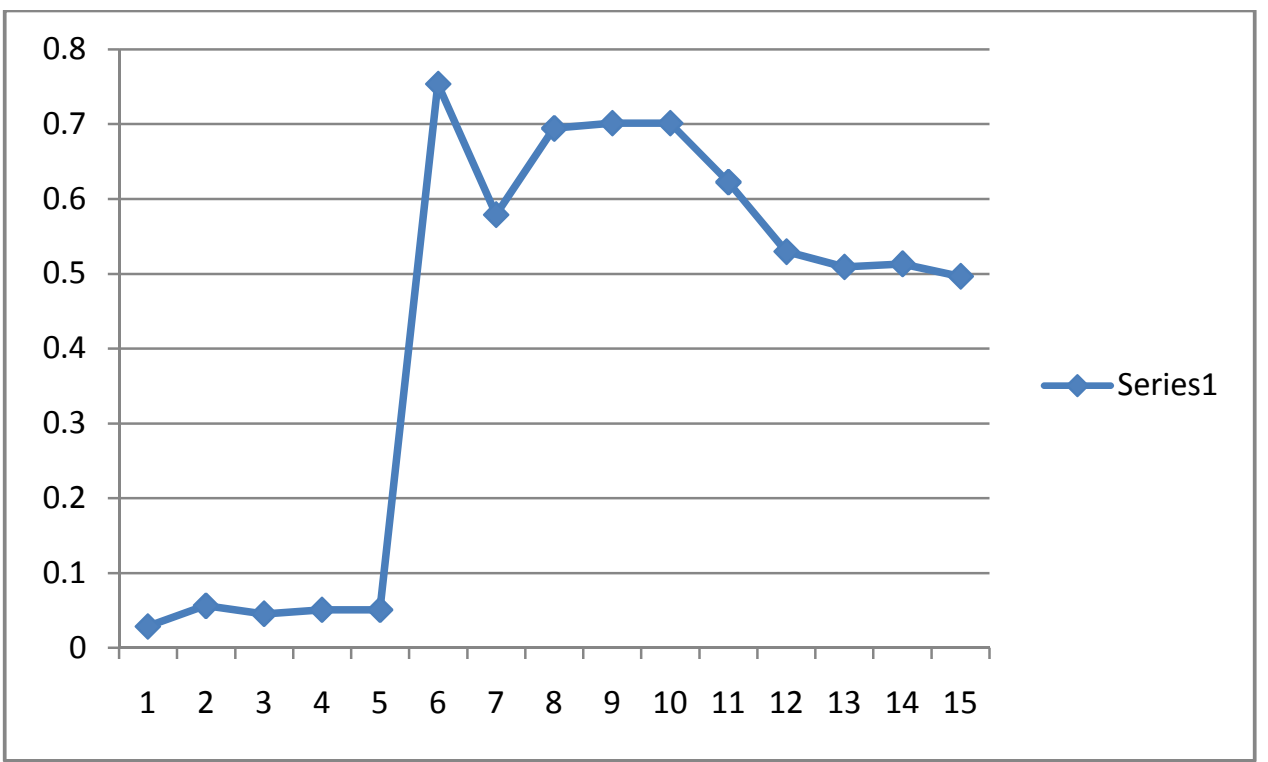

EJBE Vol. 4 No. 1/2014 
UAE: Mergers and Acquisitions

The stock market monthly returns from the post-merger period April 2007 to April 2012 indicates a cumulative return of -43.89 per cent and average returns of -0.73 per cent respectively. During the period April 2007 to March 2008, the cumulative excess return was 62 per cent. The average return during this period was 7.79 per cent. This shows that during the year surrounding the postmerger period, stock prices showed substantial gain.

\subsection{Operating Performance Analysis and Interpretation}

Table 12: Financial Parameters: Emirates NBD Consolidated data for Pre-merger and Post-merger period

\begin{tabular}{|l|r|r|r|r|r|r|r|r|c|}
\hline $\begin{array}{l}\text { Value in Billion } \\
\text { AED }\end{array}$ & Year & & & & & & & & \\
\hline Parameters & $\mathbf{2 0 0 5}$ & $\mathbf{2 0 0 6}$ & $\mathbf{2 0 0 7}$ & $\mathbf{2 0 0 8}$ & $\mathbf{2 0 0 9}$ & $\mathbf{2 0 1 0}$ & $\mathbf{2 0 1 1}$ & $\mathbf{2 0 1 2}$ & $\mathbf{2 0 1 3}$ \\
\hline Total Assets & 110.8 & 165.1 & 253.8 & 282.4 & 281.5 & 286.1 & 284.6 & 308.3 & 342.1 \\
\hline Total Liabilities & 97.5 & 150.2 & 228.6 & 256.6 & 249.6 & 252.3 & 249.7 & 271.8 & 300.3 \\
\hline $\begin{array}{l}\text { Loans and } \\
\text { Advances }\end{array}$ & 66.5 & 102.4 & 151.9 & 188 & 194.7 & 177 & 176.8 & 218.2 & 238.3 \\
\hline $\begin{array}{l}\text { Customer } \\
\text { deposits }\end{array}$ & 66.5 & 86.2 & 126.1 & 139.9 & 158 & 159.8 & 154 & 213.9 & 239.6 \\
\hline $\begin{array}{l}\text { Total Operating } \\
\text { Income }\end{array}$ & 3.8 & 4.7 & 4.9 & 8.4 & 10.8 & 9.7 & 9.9 & 10.2 & 11.9 \\
\hline Net Profit & 2.8 & 2.9 & 2.7 & 3.6 & 3.34 & 2.33 & 2.48 & 2.55 & 3.26 \\
\hline
\end{tabular}

Source: Annual reports of EBI, NBD and Emirates NBD

The year of merger was 2007. The data for the year 2005 and 2006 consist of consolidated figures for Emirates Bank International (EBI) and National Bank of Dubai (NBD) for comparative purposes. The total operating income and net profit is showing fluctuating trend during the post-merger period. Net profit decreased during the year 2007 followed by an increase in 2008, again a marginal decline in 2009 but since then a progressive upward trend is observed. Assets were showing an increasing trend except in the years 2009 and 2011. 
UAE: Mergers and Acquisitions

Table 13: Comparative Growth Rate

\begin{tabular}{|l|c|c|}
\hline $\begin{array}{l}\text { Per cent changes in growth } \\
\text { rate }\end{array}$ & $\begin{array}{c}\text { Pre-Merger } \\
\text { period }\end{array}$ & $\begin{array}{c}\text { Post-Merger } \\
\text { Period }\end{array}$ \\
\hline Total Assets & $49 \%$ & $11.26 \%$ \\
\hline Total Liabilities & $53.90 \%$ & $12.24 \%$ \\
\hline Loans and Advances & $54.12 \%$ & $23.72 \%$ \\
\hline Customer deposits & $29.65 \%$ & $10.97 \%$ \\
\hline Total operating Income & $22.50 \%$ & $70.31 \%$ \\
\hline Net Profit & $3.57 \%$ & $32.85 \%$ \\
\hline
\end{tabular}

For the comparative analysis two base periods were selected: 2005 for the premerger period and 2007 for the post-merger period. The growth rates of the financial parameters were examined in the year 2006 (for premerger period) and 2008 (for the post-merger period) with respect to their base period. It is observed that the growth rate in total assets and liabilities were greater during the pre-merger period in comparison to the post-merger period. The growth rate in loans and advances and customer deposits were higher during the premerger period. The growth rate in total operating income and net profit were higher in the post-merger period compared to the pre-merger period. The operating income and net profit increased by 70.31 per cent and 32.85 per cent respectively in the post-merger period compared to an increase of 22.5 per cent and 3.57 per cent respectively in the pre-merger period. Compared to the merger year of 2007, operating income and net profit to date has increased by 142 per cent and 21 per cent respectively. 
UAE: Mergers and Acquisitions

Table 14: Cash Flow Return on Assets

\begin{tabular}{|c|c|c|c|c|c|c|c|c|c|}
\hline $\begin{array}{l}\text { Value in Billion } \\
\text { AED }\end{array}$ & Year & & & & & & & & \\
\hline Parameters & 2005 & 2006 & 2007 & 2008 & 2009 & 2010 & 2011 & 2012 & 2013 \\
\hline Total Assets (A) & $\begin{array}{r}110.8 \\
2\end{array}$ & $\begin{array}{r}165.1 \\
5\end{array}$ & $\begin{array}{r}253.8 \\
1\end{array}$ & $\begin{array}{r}282.4 \\
1\end{array}$ & 281.5 & $\begin{array}{r}286.0 \\
7\end{array}$ & $\begin{array}{r}284.6 \\
1\end{array}$ & $\begin{array}{r}308.2 \\
9\end{array}$ & $\begin{array}{r}342.0 \\
6\end{array}$ \\
\hline $\begin{array}{l}\text { Total Operating } \\
\text { Income (B) }\end{array}$ & 3.88 & 4.75 & 4.95 & 8.46 & 10.79 & 9.72 & 9.93 & 10.22 & 11.86 \\
\hline CFA (B/A) & $\begin{array}{r}0.035 \\
0\end{array}$ & $\begin{array}{r}0.028 \\
8\end{array}$ & $\begin{array}{r}0.019 \\
5\end{array}$ & $\begin{array}{r}0.030 \\
0\end{array}$ & $\begin{array}{r}0.038 \\
3\end{array}$ & $\begin{array}{r}0.034 \\
0\end{array}$ & $\begin{array}{r}0.034 \\
9\end{array}$ & $\begin{array}{r}0.033 \\
2\end{array}$ & $\begin{array}{r}0.034 \\
7\end{array}$ \\
\hline
\end{tabular}

The operating cash flow return on assets model analysis reveals that the cash flow returns have decreased by 17 per cent during the per merger period compared to an increase of 54 per cent during the post-merger period of analysis with respect to year after merger. Comparing the merger year of 2007, the return on assets model analysis revealed that the cash flow returns have increased by 78 per cent. The increase in returns had been 54 per cent, 97 per cent, 74 per cent, 79 per cent, 70 per cent, and 78 per cent respectively during the post-merger period of analysis.

\section{Conclusion}

The synergistic benefits of merger would be realized if the merger would lead to stock holder wealth enhancement and improvement in operating performance. This study analyses the impact of the merger announcement on the shareholder wealth of Emirates Bank International and National Bank of Dubai. On the assumptions of market efficiency, the study reveals that merger announcement led to excess positive returns for the shareholders of both banks in the different shorter time window period. 
UAE: Mergers and Acquisitions

The study documents a share price return of 0.47 per cent and 4.73 per cent respectively for NBD on the day of announcement and the following day. The cumulative share price return was positive in all the time window periods except the period of -20 to +20 day. The excess return or abnormal analysis for NBD reveals that on the day after the merger announcement NBD had an abnormal return of 3.89 per cent. The CAR analysis for NBD reveals positive double digit returns during the time window of +1 to +10 and +1 to +5 day of announcement.

The operating performance analysis suggests that the growth rate in total operating income and net profit were higher in the post-merger period compared to the pre-merger period. The operating cash flow return on assets model analysis reveals that the cash flow returns have decreased by 17 per cent during the pre merger period compared to an increase of 54 per cent during the post-merger period of analysis of one year. Comparing the merger year of 2007, the return on assets model analysis revealed that the cash flow returns have increased by 78 percent. The increase in returns had been 54 per cent, 97 per cent, 74 per cent, 79 per cent, 70 per cent, and 78 per cent respectively during the post-merger period of analysis.

Mergers and acquisitions (M\&A's) continue to play an important role in shaping business activities worldwide. They have become important business strategies to help improve organizational performance. The Ethiopian economy is also growing and the quest for growth is a major driving force behind mergers and acquisitions. Studies in similar line may be carried out on different corporate merger proposals in Ethiopia and in other nations.

(Note: The currency of UAE is Emirati Dirham; 1 US\$ = AED 3.67)

EJBE Vol. 4 No. 1/2014

Page 112 
UAE: Mergers and Acquisitions

\section{References}

Anup Agrawal, Jeffrey F Jaffe and Gershon N Mandelker. 1992."The post merger performance of acquiring firms: A Reexamination of an anomaly": Journal of Finance Vol. 47-4, pp. 1605-1622.

Asquith Paul, Robert F Bruner and David W Mullins Jr. 1983.“The gains to bidding firms from merger": Journal of Financial Economics, Vol. 11, pp. 121-139.

Cornett MM, Hassan Tehranian. 1992."Changes in corporate performance associated with bank acquisitions": Journal of Financial Economics, Vol. 31 pp. 211-234.

Cornett, Marcia Millon, Tehranian, Hassan. 1992."Changes in corporate performance associated with bank acquisitions": Journal of Financial Economics, Vol.31pp. 211-234.

Dodd, Peter. 1980. "Merger Proposals, Management Discretion and Stockholder Wealth": Journal of Financial Economics,Vol. 8, pp. 105 $-137$.

Ernst \& Young's. 2013. "Year-end MENA Mergers and Acquisition (M\&A) update".

Franks J, Robert Harris and Sheridan Titman. 1991."The post merger share price performance of acquiring firms": Journal of Financial Economics, Vol. 29, pp. 81-96

Fuller Kathleen, Jeffrey Netter and Mike Stegemoller. 2004. "What do returns to acquiring firms tell us? Evidence from Firms that make many Acquisitions", Journal of Finance, Vol. 57-4 , pp. 1763-1794.

Ghosh, Aloke. 2001."Does operating performance really improve following corporate acquisitions",Journal of Corporate Finance, 7: pp. 151-178.

Healy, Paul M. Palepu, Krishna G. and Ruback, Richard S. 1992.“Does

EJBE Vol. 4 No. $1 / 2014$ 
UAE: Mergers and Acquisitions

Corporate Performance Improve After Mergers",Journal of Financial Economics, 31: pp. 135-175.

Healy, Paul M, Palepu, Krishna G and Ruback, Richard S. 1997. "Which

Takeovers are Profitable? Strategic or Financial?",Sloan Management Review, 38(4): pp.45-57.

Herman E. and Lowenstein L. 1988. "The efficiency effects of hostile takeovers. In: Auerbach A (Ed.). Knights, Raiders and Targets: The impact of hostile takeovers", National Bureau of Economic Research, Cambridge.

J F Houston, Christopher M James, Michael D Ryngaert. 2001."Where do merger gains come from? Bank mergers from the perspective of insiders and outsiders",Journal of Financial Economics, Vol. 60, pp. 285-331.

Langetieg Terence C. 1978.“An Application of a three-factor performance index to measure stockholder gains from merger",Journal of Financial Economics, Vol. 6, pp. 365-383.

Mandelker, Gershon. 1974. "Risk and Return: The Case of Merging Firms", Journal of Financial Economics, Vol. 1, pp. 303-335.

Moeller Sara B, FrederikP Schlingemann and Rene M Stulz. 2004. "Firm Size and the gains from acquisitions", Journal of Financial Economics, Vol. 73, pp. 201-228.

MoellerSara, Frederik PSchlingemann and Rene M Stulz. 2005. "Wealth Destruction on a Massive Scale? A study of Acquiring Firm Returns in the recent merger wave", The Journal of Finance, Vol. 60-2, pp. 757 $-781$.

Palepu, Krishna. 1985. "Diversification Strategy, Profit Performance and the Entropy Measure”,Strategic Management Journal, 6: pp. 239-255. Singal Vijay. 1996."Airline mergers and competition: An integration of stock 
UAE: Mergers and Acquisitions

and product price effects", Journal of Business, Vol. 69 -2 pp. 233-268.

Switzer, Jeannette A. 1996."Evidence on Real Gains in Corporate

Acquisitions", Journal of Economics and Business, 48: pp. 443-460.

Thomson Financial.2013. Institute of Mergers, Acquisitions and Alliances

(IMAA) analysis.

YAmihud, Gayle L Delong, Anthony Saunders. 2002. "The effect of cross

border bank mergers on bank risk and value", Journal of International

Money and Finance, Vol. 21, pp. 857-877.

http://gulfbusiness.com

www.emiratesnbd.com 